\title{
PFKFB4 wt Allele
}

National Cancer Institute

\section{Source}

National Cancer Institute. PFKFB4 wt Allele. NCI Thesaurus. Code C148360.

Human PFKFB4 wild-type allele is located in the vicinity of 3p21.31 and is approximately $45 \mathrm{~kb}$ in length. This allele, which encodes 6-phosphofructo-2-kinase/fructose-2,6bisphosphatase 4 protein, is involved in the regulation of glycolysis. Expression of the gene by hypoxic cancer cells is essential to their survival. 